\title{
YM-216391, a Novel Cytotoxic Cyclic Peptide from Streptomyces nobilis
}

\author{
I. Fermentation, Isolation and Biological Activities \\ Kin-ya Sohda, Koji Nagai, Takao Yamori, Ken-ichi Suzuki, Akihiro Tanaka
}

Received: October 7, 2004 / Accepted: December 10, 2004

(C) Japan Antibiotics Research Association

\begin{abstract}
YM-216391, a novel cyclic peptide, was isolated from the cultured mycelium of Streptomyces nobilis JCM 4274. It was purified by solvent extraction, silica gel and ODS flash column chromatographies, followed by preparative HPLC. YM-216391 dosedependently inhibited the growth of human cervical cancer HeLa S3 cells with an $\mathrm{IC}_{50}$ value of $14 \mathrm{nM}$. YM-216391 also showed potent cytotoxic activity against a human cancer cell line panel.
\end{abstract}

Keywords YM-216391, cyclic peptide, trisoxazole, cytotoxic

\section{Introduction}

In the course of screening for new anticancer drugs, Streptomyces nobilis JCM 4274 [1] was found to produce a novel active substance, YM-216391 (1, Fig. 1), which was determined using spectral analyses and chemical degradation to be a unique cyclic peptide. It possesses potent cytotoxicity against human cancer cell lines in vitro, and is structurally related to telomestatin (2, Fig. 1), which is a potent telomerase inhibitor isolated from Streptomyces anulatus [2], and shown to induce telomere shortening with apoptosis in myeloma and leukemia [3 5]. Additionally, some cytotoxic trisoxazole-containing macrolides that were discovered from marine organisms [6 10] have shown to target actin with high affinity and specificity [11, 12], and have the potential to function as anticancer drugs [13 15]. In this paper, we describe the fermentation, isolation, and biological activities of $\mathbf{1}$. To evaluate the profile of its anticancer activity in vitro, we used a human cancer cell line panel combined with database analysis [16, 17]. The physico-chemical properties and structure elucidation of $\mathbf{1}$ are described in the following paper [18].

\section{Materials and Methods}

\section{Microorganism}

The organism was obtained from the RIKEN BioResource Center.

\section{Cell Proliferation Assay}

HeLa S3 cells were seeded in a 96-well plate at a density of
K. Sohda (Corresponding author), K. Nagai: Institute for Drug Discovery Research, Yamanouchi Pharmaceutical Co., Ltd., 1-1-8, Azusawa, Itabashi-ku, Tokyo 174-8511, Japan, E-mail: souda@yamanouchi.co.jp

T. Yamori: Division of Molecular Pharmacology, Cancer Chemotherapy Center, Japanese Foundation for Cancer Research, 1-37-1, Kami-Ikebukuro, Toshima-ku, Tokyo 170-8455, Japan
K. Suzuki: Institute for Drug Discovery Research, Yamanouchi Pharmaceutical Co., Ltd., 21, Miyukigaoka, Tsukuba-shi, Ibaraki 305-8585, Japan

A. Tanaka: Corporate Communications Department, Yamanouchi Pharmaceutical Co., Ltd., 2-3-11, Nihonbashi-Honcho, Chuo-ku, Tokyo 103-8411, Japan 
<smiles></smiles>

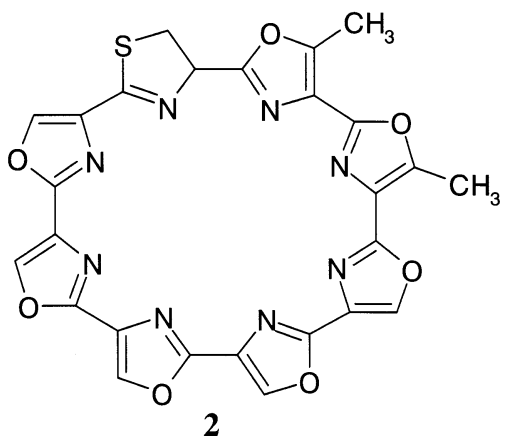

Fig. 1 Structures of YM-216391 (1) and telomestatin (2).

$1 \sim 1.4 \times 10^{4}$ cells/well in $200 \mu 1$ of MEM medium complemented with $10 \%$ fetal bovine serum. Serial dilutions of 1 were then added to wells. Control wells were treated with the vehicle (DMSO). After 72 hours of incubation at $37^{\circ} \mathrm{C}$ in a $5 \% \mathrm{CO}_{2}$ atmosphere, the medium in each well was removed and replaced with $100 \mu$ of fresh medium. Cell viability was measured as mitochondrial NADH-dependent dehydrogenase activity with a Cell Counting Kit (Dojindo) using 2-(4-iodophenyl)-3(4-nitrophenyl)-5-(2-disulfophenyl)-2H-tetrazolium monosodium salt (WST-1) [19]. Ten microliters of $5 \mathrm{mM}$ WST-1 solution containing $0.2 \mathrm{mM} \mathrm{1-methoxy-5-methyl-}$ phenazinium methosulfate (1-methoxy PMS) was added to each well. The cells were then allowed to incubate for 4 hours under the same condition as above. The absorbance of each well was measured at $415 \mathrm{~nm}$, with a reference wavelength of $630 \mathrm{~nm}$, using a MTP-32 microplate reader (Corona Electric).

\section{Human Cancer Cell Line Panel}

This experiment was carried out at the Cancer Chemotherapy Center, Japanese Foundation for Cancer Research. The screening panel consisted of the following
39 human cancer cell lines: breast cancer HBC-4, BSY-1, HBC-5, MCF-7, and MDA-MB-231; brain cancer U251, SF-268, SF-295, SF-539, SNB-75, and SNB-78; colon cancer HCC2998, KM-12, HT-29, HCT-15, and HCT-116; lung cancer NCI-H23, NCI-H226, NCI-H522, NCI-H460, A549, DMS273, and DMS114; melanoma LOX-IMVI; ovarian cancer OVCAR-3, OVCAR-4, OVCAR-5, OVCAR-8, and SK-OV-3; renal cancer RXF-631L and ACHN; stomach cancer St-4, MKN1, MKN7, MKN28, MKN45, and MKN74; and prostate cancer DU-145 and PC-3. The $\mathrm{GI}_{50}$ (50\% growth inhibition), TGI (total growth inhibition), and $\mathrm{LC}_{50}$ values for these cell lines were determined using the sulforhodamine $\mathrm{B}$ (SRB) colorimetric method. Computer processing of these values produced differential activity patterns against the cell lines (mean graphs). The mean graph was compared with those of standard compounds, including various anticancer drugs, by using COMPARE analysis. The detailed methods are described elsewhere [20].

\section{Results}

\section{Fermentation}

The seed medium consisted of glucose $1 \%$, potato starch $2 \%$, Polypeptone (Nihon Pharmaceutical) $0.5 \%$, yeast extract $0.5 \%$, and $\mathrm{CaCO}_{3}$ 0.4\% (pH 7.0). A 500-ml Erlenmeyer flask containing $100 \mathrm{ml}$ of the seed medium was inoculated with a stock culture of the producing strain maintained on a Bennet's agar slant. After incubation at $28^{\circ} \mathrm{C}$ for 4 days on a rotary shaker set at $200 \mathrm{rpm}, 2 \mathrm{ml}$ of the seed culture was transferred to each of twenty five 500$\mathrm{ml}$ Erlenmeyer flasks containing $100 \mathrm{ml}$ of the production medium which consisted of potato starch $3 \%$, yeast extract $1.5 \%, \mathrm{KH}_{2} \mathrm{PO}_{4} 0.05 \%, \mathrm{MgSO}_{4} \cdot 7 \mathrm{H}_{2} \mathrm{O} 0.05 \%$, and $\mathrm{CaCO}_{3}$ $0.2 \%(\mathrm{pH} 7.0)$. The fermentation was carried out at $28^{\circ} \mathrm{C}$ for 7 days on a rotary shaker set at $200 \mathrm{rpm}$.

\section{Isolation}

The isolation scheme for $\mathbf{1}$ is shown in Fig. 2. A mycelial cake obtained from the fermentation broth (2.5 liters) was extracted with $\mathrm{Me}_{2} \mathrm{CO}$. After concentrating to remove the $\mathrm{Me}_{2} \mathrm{CO}$, water was added to dilute any residual $\mathrm{Me}_{2} \mathrm{CO}$. The solution was then extracted twice with EtOAc. The organic layer was concentrated in vacuo and the residue was defatted by partitioning between $\mathrm{MeOH}$ and hexane. The $\mathrm{MeOH}$ layer was concentrated in vacuo and subjected to silica gel flash column chromatography (Kieselgel 60, 70 230 mesh, Merck) with hexane - EtOAc (1:1), $\mathrm{CHCl}_{3}$ - 

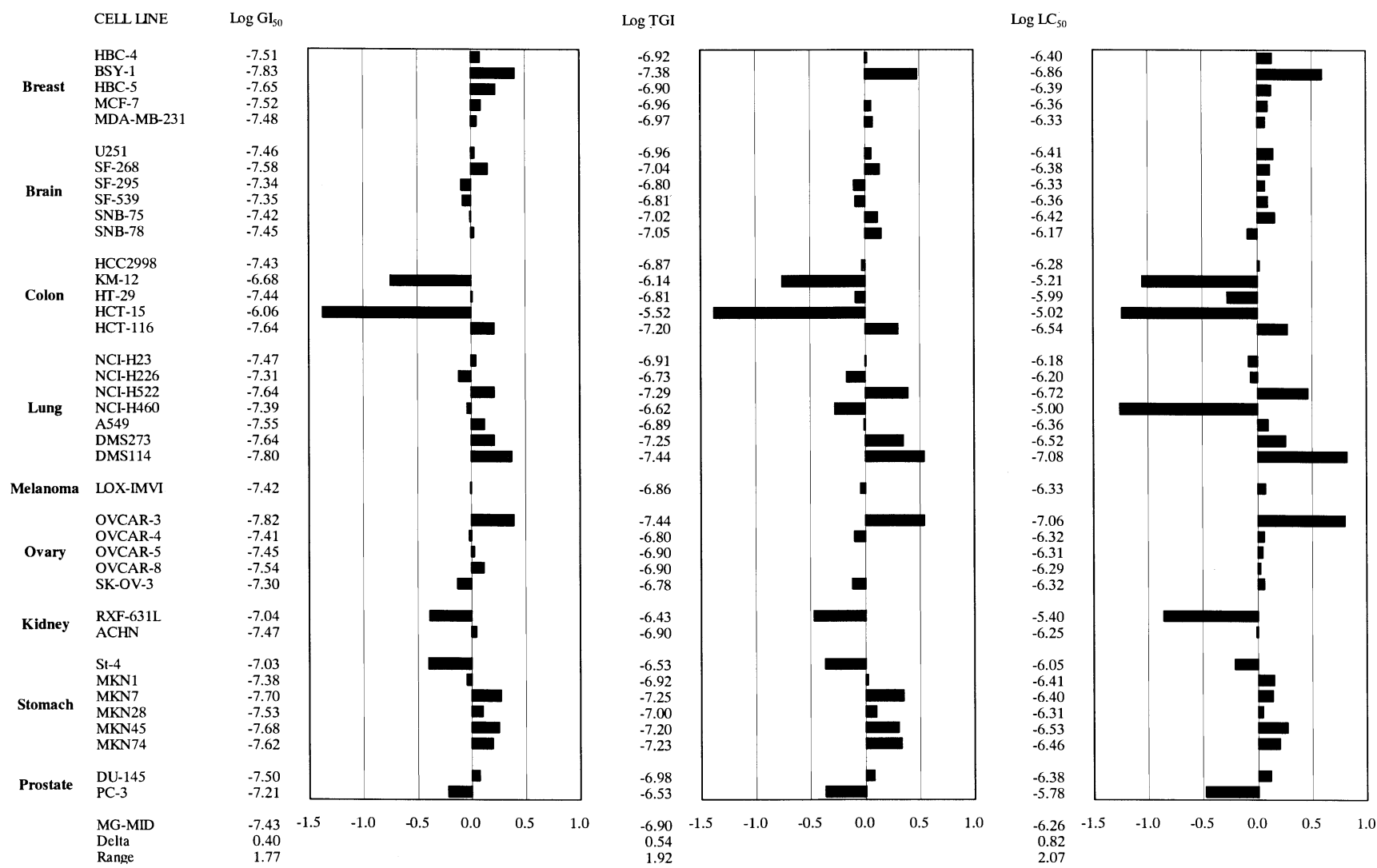

Fig. 2 Differential activity patterns for YM-216391 (1) against 39 human cancer cell lines. MG-MID: mean of logX values $\left(X=G_{50}, T G I\right.$, and $\left.L C_{50}\right)$. Delta: logarithm of the difference between the MG-MID and the log $X$ of the most sensitive cell line. Range: logarithm of the difference between the $\log X$ of the most resistant cell line and the $\log X$ of the most sensitive cell line.

$\mathrm{MeOH}(50: 1)$, and $\mathrm{CHCl}_{3}-\mathrm{MeOH}(20: 1)$ in this order. The active fraction, eluted with $\mathrm{CHCl}_{3}-\mathrm{MeOH}(20: 1)$, was concentrated in vacuo and then applied to a reverse-phase flash column (YMC * GEL ODS-A 120-230/70, YMC) with a step gradient of aqueous $\mathrm{MeOH}$. The active fractions, eluted with $70 \%$ and $80 \%$ aqueous $\mathrm{MeOH}$, were combined, evaporated to a small volume, and recrystallized by adding $\mathrm{MeOH}$. Final purification was achieved by repeated preparative HPLC (PEGASIL ODS, $250 \times 20 \mathrm{~mm}$, Senshu Scientific) with $85 \%$ aqueous $\mathrm{MeOH}$ to yield $70 \mathrm{mg}$ of $\mathbf{1}$ as a white powder.

\section{Biological Activities}

We examined the inhibitory activity of $\mathbf{1}$ against the growth of human cervical cancer HeLa S3 cells using the WST-1 colorimetric method as described in the materials and methods section. The compound dose-dependently inhibited the growth of HeLa S3 cells with an $\mathrm{IC}_{50}$ value of $14 \mathrm{nM}$. To investigate the profile of its anticancer activity in vitro, we used a human cancer cell line panel combined
Table 1 List of the compounds with growth inhibitory patterns similar to that of YM-216391 (1).

\begin{tabular}{|c|c|c|c|}
\hline Rank & Compounds & $\begin{array}{c}\text { Correlation } \\
\text { coefficient } \\
\text { with } \mathbf{1}\end{array}$ & $\begin{array}{l}\text { Molecular targets/ } \\
\text { Drug type }\end{array}$ \\
\hline 1 & Actinomycin D & 0.727 & $\begin{array}{l}\text { DNA-dependent } \\
\text { RNA polymerase inhibitor }\end{array}$ \\
\hline 2 & FR901228 & 0.718 & Histone deacetylase inhibitor \\
\hline 3 & Epirubicin & 0.617 & DNA intercalater \\
\hline
\end{tabular}

with COMPARE analysis. The differential activity patterns for $\mathbf{1}$ against 39 human cancer cell lines (mean graphs) are shown in Fig. 2. The compound exhibited potent cytotoxic activity, and its means for $\log \mathrm{GI}_{50}, \log \mathrm{TGI}$, and $\log \mathrm{LC}_{50}$ values were $-7.43(37 \mathrm{nM}),-6.90(126 \mathrm{nM})$, and -6.26 $(550 \mathrm{nM})$, respectively. In addition, 1 showed slightly weak differential activity, with the BSY-1, DMS114, and 
OVCAR-3 cell lines being more sensitive than other cell lines. The colon cancer KM-12 and HCT-15 cell lines were more resistant than other cell lines. The COMPARE analysis of 1 revealed that its mean graph did not match that of a standard anticancer drug. The three drugs ranked in the order of their correlation coefficients are shown in Table 1.

\section{Discussion}

A human cell line panel screening can potentially produce several results. Firstly, the panel may be used to identify compounds which possess the ability to effect the growth of human cancer cell lines. The compound $\mathbf{1}$ was observed to inhibit the cell growth of these cell lines $\left(\mathrm{GI}_{50}\right.$ and TGI values) and cause cell death $\left(\mathrm{LC}_{50}\right.$ value). This suggests that the treatment of human cancer cells with $\mathbf{1}$ may result in apoptosis. Additionally, if the mean graph of the test compound can be matched to that of a standard anticancer drug, then the potential target or mechanism of action may be identified. The COMPARE analysis of $\mathbf{1}$ produced no strong correlation to its mean graph, but showed correlations with actinomycin D, FR901228, and epirubicin. This result indicates two alternative possibilities: first, $\mathbf{1}$ has a unique mode of action; second, 1 's mode of action involves that of these standard anticancer drugs. In spite of the correlation with FR901228, 1 exhibited no inhibitory activity against histone deacetylase (HDAC) even at a dose of $10 \mu \mathrm{M}$ (data not shown). Meanwhile, based on the structural relationship with telomestatin (2), 1 may exhibit inhibitory activity against telomerase. Interestingly, according to the report [21], 1's growth inhibitory effects on MCF-7 and OVCAR3 , and SK-OV-3 cell lines were 50 250 times greater than those of $\mathbf{2}$. It is unclear whether this is due to the difference in the mode of action between $\mathbf{1}$ and $\mathbf{2}$. Further pharmacological studies and an investigation of the mechanism of action are now underway.

Acknowledgments We thank Mr. M. Taniguchi for supplying the compound to the Cancer Chemotherapy Center, and Mr. N. Shindoh for the HDAC inhibitory activity assay.

\section{References}

1. Baldacci E, Locci R, Farina G. Study of a new species of Streptomyces: Streptomyces nobilis sp. nov. and examination of related strains belonging to the genera Streptomyces, Streptoverticillium and Nocardia. Mycopathol Mycol Appl
26: 333-348 (1965)

2. Shin-ya K, Wierzba K, Matsuo K, Ohtani T, Yamada Y, Furihata K, Hayakawa Y, Seto H. Telomestatin, a novel telomerase inhibitor from Streptomyces anulatus. J Am Chem Soc 123: 1262-1263 (2001)

3. Nakajima A, Tauchi T, Sashida G, Sumi M, Abe K, Yamamoto K, Ohyashiki JH, Ohyashiki K. Telomerase inhibition enhances apoptosis in human acute leukemia cells: possibility of antitelomerase therapy. Leukemia 17 : 560-567 (2003)

4. Shammas MA, Reis RJ, Li C, Koley H, Hurley LH, Anderson KC, Munshi NC. Telomerase inhibition and cell growth arrest after telomestatin treatment in multiple myeloma. Clin Cancer Res 10: 770-776 (2004)

5. Sumi M, Tauchi T, Sashida G, Nakajima A, Gotoh A, Shinya K, Ohyashiki JH, Ohyashiki K. A G-quadruplexinteractive agent, telomestatin (SOT-095), induces telomere shortening with apoptosis and enhances chemosensitivity in acute myeloid leukemia. Int J Oncol 24: 1481-1487, 2004

6. Roesener JA, Scheuer PJ. Ulapualide A and B, extraordinary antitumor macrolides from nudibranch eggmasses. J Am Chem Soc 108: 846-847 (1986)

7. Matsunaga S, Fusetani N, Hashimoto K. Kabiramide C, a novel antifungal macrolide from nudibranch eggmasses. J Am Chem Soc 108: 847-849 (1986)

8. Fusetani N, Yasumuro $\mathrm{K}$, Matsunaga $\mathrm{S}$, Hashimoto $\mathrm{K}$. Mycalolides $\mathrm{A} \sim \mathrm{C}$, hybrid macrolides of ulapualides and halichondramide, from a sponge of the genus. Tetrahedron Lett 30: 2809-2812 (1989)

9. Matsunaga S, Fusetani N, Hashimoto K, Koseki K, Noma M, Noguchi H, Sankawa U. Bioactive marine metabolites. 25. Further kabiramides and halichondramides, cytotoxic macrolides embracing trisoxazole, from the Hexabranchus eggmasses. J Org Chem 54: 1360-1363 (1989)

10. Kobayashi J, Murata O, Shigemori H. Jaspisamides $\mathrm{A} \sim \mathrm{C}$, new cytotoxic macrolides from the Okinawan sponge Jaspis sp. J Nat Prod 56: 787-791 (1993)

11. Saito S, Watabe S, Ozaki H, Fusetani N, Karaki H. Mycalolide B, a novel actin depolymerizing agent. J Biol Chem 269: 29710-29714 (1994)

12. Spector I, Braet F, Shochet NR, Bubb MR. New anti-actin drugs in the study of the organization and function of the actin cytoskeleton. Microsc Res Tech 47: 18-37 (1999)

13. Jordan MA, Wilson L. Microtubules and actin filaments: dynamic targets for cancer chemotherapy. Curr Opin Cell Biol 10: 123-130 (1998)

14. Yeung KS, Paterson I. Actin-binding marine macrolides: total synthesis and biological importance. Angew Chem Int Ed Eng1 41: 4632-4653 (2002)

15. Fenteany G, Zhu S. Small-molecule inhibitors of actin dynamics and cell motility. Curr Top Med Chem 3: 593-616 (2003)

16. Yamori T. Panel of human cancer cell lines provides valuable database for drug discovery and bioinformatics. Cancer Chemother Pharmacol 52 Suppl. 1: 74-79 (2003) 
17. Dan S, Tsunoda T, Kitahara O, Yanagawa R, Zembutsu H, Katagiri T, Yamazaki K, Nakamura Y, Yamori T. An integrated database of chemosensitivity to 55 anticancer drugs and gene expression profiles of 39 human cancer cell lines. Cancer Res 62: 1139-1147 (2002)

18. Sohda K, Hiramoto M, Suzumura K, Takebayashi Y, Suzuki K, Tanaka A. YM-216391, a novel cytotoxic cyclic peptide from Streptomyces nobilis. II. Physico-chemical properties and structure elucidation. J Antibiot 58: 32-36 (2005)

19. Ishiyama M, Shiga M, Sasamoto K, Mizoguchi M, He P. A new sulfonated tetrazolium salt that produces a highly water- soluble formazan dye. Chem Pharm Bull 41: 1118-1122 (1993)

20. Yamori T, Matsunaga A, Sato S, Yamazaki K, Komi A, Ishizu K, Mita I, Edatsugi H, Matsuba Y, Takezawa K, Nakanishi O, Kohno H, Nakajima Y, Komatsu H, Andoh T, Tsuruo T. Potent antitumor activity of MS-247, a novel DNA minor groove binder, evaluated by an in vitro and in vivo human cancer cell line panel. Cancer Res 59: 4042-4049 (1999)

21. Shin-ya K. Telomerase. Saishin Igaku 56: 384-389 (2001) in Japanese 